Földi Katalin

\title{
Növekvő koncentráció, élesebb verseny
}

\author{
- Kiskereskedelmi szolgáltatások szerepe és földrajzi elönyök \\ kapcsolata - Mi a helyzet Jász-Nagykun Szolnok megyében?
}

\begin{abstract}
Katalin Földi: The Significance of Retail Services, Their Connection to the Geographical Location, Retail Services in Jász-Nagykun-Szolnok County Nowadays the question as to what can make the customer satisfied and loyal to a shop is getting more and more important. One of its potential tools is the introduction of retail services, which has a significant role in the increasing importance of services, too. Not only retail, but also services are part of our everyday life and pervade it. Retail satisfies our needs and demands through buying. In concentrated retailing, the competition among competitors is becoming more and more intense. In this competition, a retail service can become a relative competitive edge. These services have to follow customer demands as well as have to be hard to copy by competitors, i.e. they have to be sustainable in the long run. The quality and standard of a specific retail service depends on the place/ area of requisition, the exact retail unit, the current employee and his/ her level of compensation in the organisation.
\end{abstract}

\section{Bevezetés}

Azt a témát választottam, hogy Jász-NagykunSzolnok megyében vizsgáljam az egyes településeken mũködõ kereskedelmi egységek tipusát, ès az általuk kinált kereskedelmi szolgáltatásokat. A Ph.D munkámhoz a kereskedelmi szolgáltatások kapcsolódnak, szolnoki lakhelyem miatt pedig a Jász-Nagykun-Szolnok megyét helyezetem elérdeklödésem fókuszpontjába. Azért érzem a témaválasztásomat idōszerũnek, mert a kereskedelem játszik szerepet abban, hogy a termékeket és szolgáltatásokat eljuttassa a fogyasztókhoz, áthidalja a termelés és fogyasztás kőzötti térbeli, időbeli, mennyiség és vảlaszték szerinti eltéréseket. A kereskedelem fejlödése a koncentráció szakaszában jár, azaz egyre kevesebb vállalkozás bonyolít egyre magasabb forgalmat, emiatt a verseny rendkivūli módon kiélezett. A kiskereskedelmi horizontális verseny dimenziója az árban, költségben megjelenõ hatékonyság, méret- és tevékenységi kōr- ből eredō gazdaságosság, földraizi elōnnyōk, termék választék (minöség és skála) és kiskereskedelmi szolgáltatások minősége és szintjei. Ezen dimenziókból a termék hozzáadott értékének nōvelésében szerepet játszó, és bizonyos esetekben a boltválasztást is befolyásoló kiskereskedelmi szolgáltatásokat teszem vizsgálatom tárgyává Jász-Nagykun-Szolnok megyében.

\section{Szolgáltatások növekvỗ jelentősége}

A társadalmi modernizáció egyik legfontosabb eleme az anyagi javakat elōállitó ágazatok részarányának csōkkenése a foglalkoztatás szerkezetében, ès a többi ágazat - amelyeket összefoglalóan harmadik szektornak nevezünk részarány-növekedése. E változásnak több oka van: szükségletek szerkezetváltozása, a termelékenység eltérő tendenciảja ès a társadalmi munkamegosztás elmélyülésének eredménye. (Illés Iván [2003] 363. old.)

A magyarországi szolgáltatások fejlõdésében 
Gazdaságtudományok

négy szakaszt külōnitenek el. A jelenlegi, a negyedik szakaszt a szolgáltatások elől járó, felzárkózó fejlesztési szakaszának nevezik. Ez az etap egyes területeken szakmailag a nyolcvanas évek utolsó harmadában kezdődōtt, a tercier szektor egészére azonban csak a rendszerváltással, a piacgazdaságra való áttéréssel terject ki.

A tercier szektor részesedése GDP-ben és a foglalkoztatottak, valamint az aktiv keresők létszámából 2/3 kőrül mozog, a bruttó kibocsátásban csak 50\% körüli. A Leader Program - a vidéken épülŏ Európa tanulmány szerint a szolgáltatásban foglalkoztatottak aránya a dominánsan rurális régiókban $56,7 \%$, a szignifikánsan rurális régiókban $63,1 \%$ és a dominánsan urbánus régiókban $70,2 \%$. Vannak olyan információk, hogy az elmaradottabb területeken a közfoglalkoztatottak részesedése a szolgáltatásokban ennél magasabb (Eurpoean Commission, [2004]).

Hazánkban a szolgáltatások részaránya az importban 2002-ben 16,3\% volt, ez majdnem annyi mint az Amerikai Egyesült Államokban, viszont Ausztriában és Japánban ez a mutató csaknem a kétszerese a magyar értéknek, és Franciaország esetében azonban még a $10 \%$-ot sem éri el.

Szakirók egy csoportjának véleménye szerint egy ország gazdasági fejlettségét meg lehet ítélni annak alapján, hogy a GDP milyen részaránya származik a tercier szektorból. Ez alapján hazánk még nem a fejlett, de már nem a fejlõdõ országok csoportjába tartozik, hanem a kettŏ között szerepel. Ha a fenti értékeket néhány évre visszamenően vizsgájuk, akkor látható, hogy a GDP-n belüli részaránya fokozatosan növekszik. Más szakértők viszont tagadják, nem véletlenül, hogy a tercier szektor részesedése a GDP-ből kielégitó adat lenne a gazdasági fejlettség megítélésére.

\section{Szolgáltatások és a földrajzi elhelyezkedés}

A szolgáltatások négy elsõdleges tulajdonságát az angol elnevezések röviditése alapján HIPI- elvnek nevezik, ezek egyrészt a szolgáltatások gyengeségei, másrészt bizonyos nézõpontból az erősségei is egyben. Ezek a heterogenitás, nem tárolható jelleg, megfoghatatlanság és elválaszthatatlanság. Ezek közül az elválaszthatatlanságot emelem ki, mert ennek van jelentõsége terūletileg.

A szolgáltatás egyszerre „termelődik" és ,fogyasztódik" el, azaz az elóállitása és a fogyasztása nem választható el egymástól: ebben áll a szolgáltatás teljesitésének és igénybevételének elválaszthatatlansága (Veres [1998] 39. old.). Igy a szolgáltatók földrajzi elhelyezkedése, szakmai felkészültsége stb. tényezők meghatározzák, hogy az igénybevevők milyen minőségũ szolgáltatáshoz juthatnak. Az 1980-as években az amerikai marketing kutatások eredményei alapjản összeállitottak 10 minőségparamétert, ezek közül az egyik az elérhetôség. Az elérhetöséget nem csak földrajzilag gondolták, hanem mondjuk a világhálót, telefonkapcsolat lehetôségeként is, de a dolgozatom szempontjából csak földrajzi szempontot emelem ki.

A szolgáltatásoknak a piachoz, a fogyasztókhoz kell települnie, sohasem szakadhatnak el tôllük. Szolgáltatások jellemzôi, hogy kevésbé veszik igénybe a föld kimerithetõ eröforrásait, munkaigényūk nagy és növekvő. Rendszerjelleg jelemzi, melyben az egyes részelemek között meghatározott funkciómegosztás van. A kereskedelemben a felvásárló, a nagy-és kiskereskedelem alkot sajátos rendszert. (lliés Iván [2003] 364. old.)

A szolgáltatások jövedelemrugalmassági szempontból rendkivül mozgékonyak, igy az egyesfogyasztók, illetve háztartások esetében a kereslet erösen függ a diszkrecionális jövedelemtől és annak változásától. Amennyiben a családi költségvetésben váratlan kiadások adódnak, illetve csökken a jövedelem, és ezért alacsonyabb keretbōl kell gazdálkodniuk, akkor elöször a szolgáltatásokról fognak lemondani. (Persze ezzel ellentétes módon is reagálhatnak, ha presztizsfogyasztást szimbolizál az adott szolgáltatás.)

ECONOMICA 2008/1

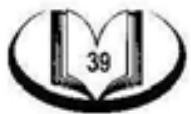


Földi Katalin: Növekvő koncentráció, élesebb verseny

\section{Szolgáltatások csoportjai}

László és Deák szerzőpáros szerint a szolgáltatások csoportositása a szakirodalomban rendkivül valltozatos, néhányat emlitek közülük:

a) A tevékenység tartalmát tekintve,

b) marketing szemlélet alapjản,

c) szektorok szerinti csoportok,

d) statisztikai számbavétel alapján,

e) társadalomban betöltött szerepe szerint,

f) egyéb csoportositások.

\section{a) Tevékenység tartalmát tekintve}

- Kommunális szolgáltatások

- Testápolás, tisztitás

- Vendéglátás

- Szórakozás, mûvelödés

- Utazás, szállitás, hírkōzlés

-Egészségügyi, népjóléti szolgáltatás

- Pénzügyek és bizlositások

- Oktatás, kutatás

- Jogi és gazdasági szolgáltatások

- Hatóságok, intézmények

Marketing szemlélet szerint fogadott, szakmai, mũszaki és birtokbavételi szolgáltatások.

Szektorok szerinti csoportok, kitermelés, feldolgozás, elosztó, termelöi, társadalmi és személyi szolgáltatások. Statisztikai számbevétel szerint a KSH oldalán is megtalálható TEÁOR szerinti tevékenység-csoportok találhatóak, melyeknél 2008. január 1-én már az új ,beosztás" lépett életbe. A társadalomban betöltött szerepük alapján orientációs, termelō, transzformációs, fenntartó, regeneráló és egyéb szolgáltatások vannak.

A Németh-Papp szerzöpáros a pénzügyi szolgalltatások közé a banki, pénzintézeti, biztositási és értékpapir szolgáltatásokat sorolja.

A Browning-Singelmann primer, szekunder és tercier szektort különböztet meg. A tercier szektorba az elosztó, a társadalmi és a személyi szolgáltatásokat sorolja. Az elosztó szolgáltatásba tartozik a szállitás és raktározás, távközlés mellett a nagykereskedelem és a kiskereskedelem (kivéve az élelmiszerek és italok árusitását).
Ez utóbbit a személyi szolgáltatások kỏzé, az éttermek ès italboltok csoportba teszik.

Piaci ès nem piaci szolgáltatások bontás szerint a piaci szolgátatásoknak három csoportját különiţük el: a termelési, az elosztással kapcsolatos és a személyi szolgáltatások. (Papp [2003] 21. old.) A piaci szolgáltatásokon belül az elosztással kapcsolatos szolgáltatások a logisztikai, az infokommunikációs és a kereskedelmi szolgáltatások. A továbbiakban az utóbbit veszem górcsỏ alá.

\section{Az üzletek szakosodása, települési és területi szerkezete}

Az 1990-es években félszáz nagy bevásárlókôzpont épült hazánkban, csaknem $60 \%$-uk a fôvárosban, a tōbbi vidéki városokban. Ezek a bevásárlóközpontok szabadidõ ès szórakoztató centrumként is müködnek. Becslések szerint a fövárosban a non-food forgalom közel felét a már magukhoz kapcsolták, vidéken ennél alacsonyabb részarányt képviselnek. Azon túlmenően, hogy kellemes és kulturált vásárlási kōrülményeket kínálnak, számos nem elhanyagolható negativ hatást is gyakorolnak az adott település kereskedelmi szerkezetére. Vásárlóerõt vonnak el a település központjában lévõ ũzletekböl és utcákból. Számos üzletet ez a veszteséges mükōdés, illetve a csőd felé sodort. Lènyeges átrendezôdés tapasztalható a városok területén belül, kiszorulnak a központból azok az üzletek, melyek forgalma kevésbé érzékeny a centrális fekvésre, illetve amelyek a magas bérleti djakat már nem tudták kigazdálkodni a forgalmukból. A bevásárókōzpontok építészetileg az internacionális jellemzőkkel birnak, igy szinte megkülönböztethetetlenek egymástól.

A diszkont áruházak általában a városok kūlterūletein jöttek létre, az áruik egy részét gyũjtócsomagolásban, vagy akár a raklapokról értékesítik, ezért alacsonyabbak az áraik, mint a központi áruházaknak.

A szupermarketek szintén városok külső terūletein települtek, food és non-food kategóriába tartozó termékek értékesitésével foglalkoznak, 


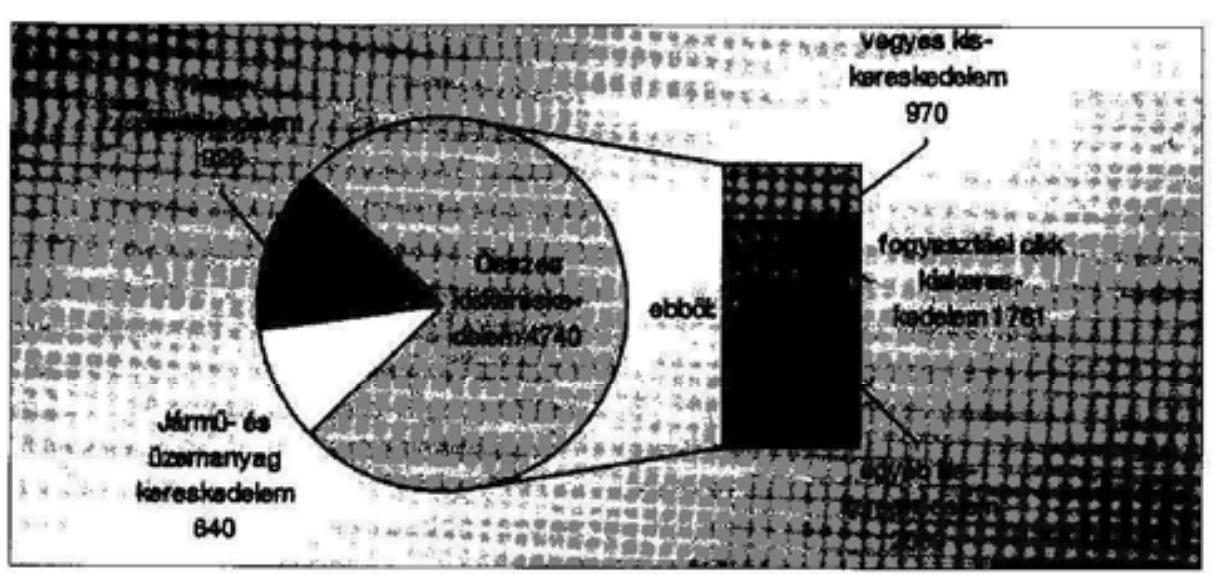

1. ábra. A kereskedelomben müködő vállallkozások megoszlása (db)

Forrás: Jász-Nagykun-Szolnok megye az Európai Unió kapujáăan 48. p.

nagy eladóterūlettel rendelkeznek, önkiszolgáló értékesitési mód jellemzo̊ rájuk valamint az, hogy személygépkocsival, illetve a hipermarketek esetében az áruház rendszeresitett buszjáratával jól megközelíthetőek. A szuper-, és hipermarketek közötti különbség elsõsorban az eladótér nagyságában, a választék szélességében és mélységében, a polcok regálméterében érhető tetten.

Hazánkban több mint 5 ezer élelmiszer áruház mũködik, az ország több mint 500 településére koncentrálódnak. A hálózat $3 / 4$-e szaküzlet. A szaküzleti hálózatban is strukturális és területi szerkezeti átalakulások mennek végbe.

Szinte minden településtipust érint az üzletek számának növekedése, de eltérések vannak a mértékében. Általánosságban az jellemzō, hogy minél nagyobb népességũ és magasabb szerepkörũ a település, annál nagyobb az üzletek számának növekedése. A ruházati boltokra ez kūlönösen jeilemzō. Az iparcikk kereskedelmet illetõen minden településkategóriában nagymértékü volt a hálózat bővülése.

A ruházati és az iparcikk boltoknak Magyarországon ma is $23 \%$-a Budapesten, $16 \%$-a a 100 ezer lakos feletti nagyvárosokban, összességében $87 \%$-a a városokban és mindössze $13 \%$-a a községekben, ezen belül 1,2\%-a az 1000 lakosnál kisebb községekben müködik. Az 1000 lakosnál kisebb községek 78\%-ában nincs szak- ūzlet (éleimiszeren kivül). (illés Iván [2003] 417. old.)

Élelmiszer jellegũ, vegyes üzletek döntöen a falvakban taláhatók, de az elmúlt években a városokban is dinamikusan nőtt a számuk.

A Központi Statisztikai Hivatal 2006. szeptember 30-án kelt közlése szerint az 5,7 ezer üzletnyitás és 6,5 ezer üzletbezárás eredményeként 780-nal, 0,5 százalékkal kevesebb üzlet műkōdött, mint az év kōzepén. Az ũzletállomány 2006. III. negyedévi szúkülése országos méreteket öltött, szeptember végére megyénként átlagosan kōzel 40-nel csökkent az üzletek száma június végéhez viszonyitva, egyedül Toina megyében nem volt figyelemre méltó változás. Szeptember végén Budapesten összpontosult az országos üzlethálózat 20 százaléka, KözépMagyarország aránya 30 százalék, a többi régió részesedése 10-15 százalék között alakult. (OrientPress - MCOnet KSH felmérés)

\subsection{A kereskedelem teljesítménye és struktúrája Jász-Nagykun-Szolnok megyében}

A lakosságot ellátó megyei kiskereskedelmi üzlethálózat a rendszerváltás óta látványosan fejlödött. A 2000-ben mưkōdő 5800 bolt több mint másfélszerese volt az 1990. évinek. Ezzel párhuzamosan jól érzékelhetöen bõvūlt az 
Földi Katalin: Növekvõ koncentráció, élesebb verseny

àrukinálat és javultak a vásárlási körülmények. Ennek eilenére az üzletsürüség a térségben viszonylag alacsony, egy négyzetkilométerre egy kiskereskedelmi bolt jut, 10 ezer lakosra 140 , ami a 3. és 5. legalacsonyabb a megyék rangsorában. 2002-ben a fenti értékek 1,1 kiskereskedelmi bolt/km², és 10 ezer lakosra 147, ez 17 ., illetve 16. hely a megyék között. Viszont 2003 . ban már 6250 kereskedelmi vállalkozás müködött, ezek $75 \%$-ának a kiskereskedelem volt a fo̊ tevékenységi köre, igy 1000 lakosra már 15 kiskereskedelmi egység jutott. A területi elhelyezkedésben nagyok a kūlönbségek.

A boltok egyharmada a megyeszékhelyet is magába foglaló szolnoki kistérségben koncentrálơdik, ötōde pedig a Jászságban található, más kistérségek részesedése az üzlethálózatból 7-11\% kōzött mozog. Ezek a különbségek igazak a fentebb számolt 1000 lakosra jutó kiskereskedelmi üzletek számára is. A megyei 15-0̄s értéket csak a szolnoki térség haladja meg (17), a legkevésbé ellátott pedig a kunszentmártoni (13). A kereskedelemben müködõ vállalkozások megoszlását az 1. ábra tárja elénk. A megyei bolthálózat $25 \%$-a élelmiszer jellegũ ũzletek és áruházak, a másik $25 \%$ pedig az egyéb iparcikk üzlet.

A növekedés mellett átalakult a megyei üzlethálózat szerkezete és profilla. 2000 őszén a kiskereskedelmi üzletek gazdasági szerkezetét vizsgálva azt látjuk, hogy az egyéni vállalkozók ès a gazdasági szervezetek majdnem fele-fele arányban részesednek, $6 \%$-0s elōnyre az egyéni vállalkozások tesznek szert.

Az üzletek forgalma szoros kapcsolatban áll a lakosság jövedelmével, a kialakult árszínvonallal és a fogyasztással. A forgalom volumene - az országos tendenciával megegyezóen 1997-ig folyamatosan csökkent, ekkor a kiskereskedelem vendégiátó ûzlethálózata 107 milliárd forint forgalmat bonyolitott le. A lakosság életszinvonalának egyik jellemzője, hogy az egy lakosra jutó vásárlások értéke az országos mutatónak alig több mint $80 \%$-át tette ki. Ezt kővetően a forgalom mennyisége jelentŏsen nött a megyében és országosan is, nagyjából az évtized eleji szintet elérte 2000-ben.

A kistérségekre jellemzõ kiskereskedelmi üzlethálózatok adatait az alábbi 2. ábra prezentálja.

A kereskedelem jellemzően magánkẻzbe került, illetve az áfészek jogutódszervezeteinél maradt. A multinacionális kereskedelmi láncok, elsősorban szupermarketjeikkel vannak jelen a megyében. Országos jelentõségü a szolnoki TISZA-COOP Rt és a COOP kereskedelmi lànc szolnoki és jászberényi székhelyũ szervezete, ezek ũzletei fontos szerepet töltenek be a települések élelmiszer és napi cikk ellátásában. Látványosan bővültek a tranzitforgalomhoz és a kōzlekedéshez kapcsolódó szolgáltatások. A diszkontáruházak mellett a megyében megkésve ugyan, de megjelentek a hipermarketek is.

A Gfk. Hungária Piackutató Intézet vizsgálata szerint a megye a sor vége táján kullog a vá-

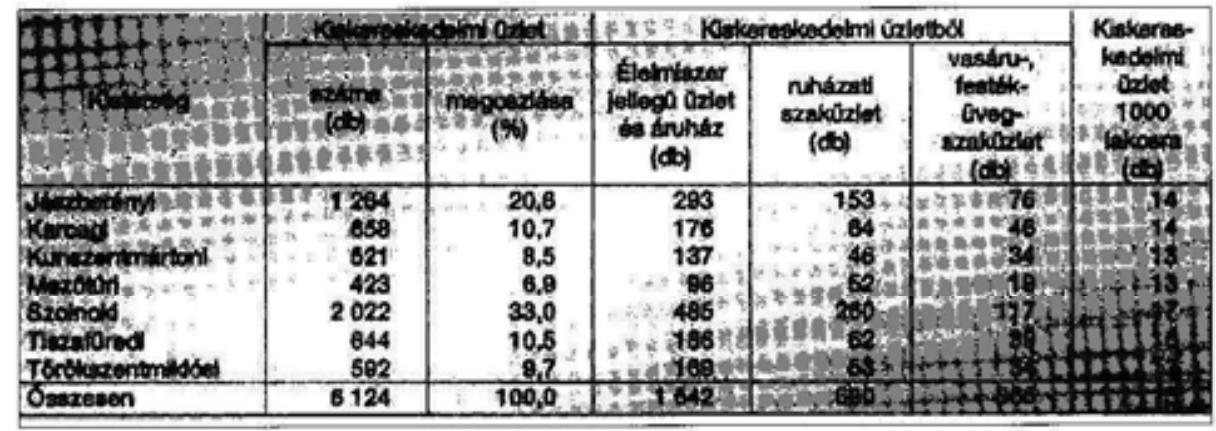

2. ábra. Kiskereskedelmi üzlethálózat jellemzôi Forrás: Jász-Nagykun-Szolnok megye az Európai Unió kapujában 48. p. 
sárlóerơ rangsorában. Az 2004-hez képest két helyet csúszott vissza. 3144 település és a fôváros 23 kerúletét vizsgálták, a megyék és kistérségek lakónépességének egy fơre jutó vásárlóerejét. Györ-Moson-Sopron a leggazdagabb, a föváros kerületei közül a második vezet, Jász-Nagykun Szolnok a 17-ik, az országos átlaghoz viszonyitott legalacsonyabb értékek $80-85 \%$-át négy megyében mérték, JászNagykun-Szolnok $85,1 \%$, Békés $(83,3 \%)$, Borsod-Abaúj-Zemplén (83,0\%), Szabolcs-Szatmár-Bereg megye $(80,3 \%)$.

A reálkeresetek csökkenésével is szembesülnek a forgalmazók.

Egy év alatt $3 \%$-kal nött a megye kiskereskedelmi üzlethálózata a boltok számát tekintve. 2005. március végén 6317 üzletben vásárolha. tott a lakosság, ez az egy évvel ezelöttihez képes 200 üzletes bővülést jelent. Viszont csökkent az egyéni válalkozók ältal müködtetett üzletek száma és aránya (1-2\%-kal) is, az összes kiskereskedelmi egység alig felét üzemeltették. A kiskereskedelmi forgalom régiós adatai jármü-, és üzemanyag-kereskedelem nélkül negyedévenként 7,8, 3 és $3 \%$-kal növekedett az elöző év azonos időszakához viszonyitva.

\section{Kereskedelmi szolgáltatások}

Kereskedelem fogalmát kétféleképpen szokták értelmezni, egyrészt szervezetként, másrészt tevékenységként. A kereskedelem számos funkciót tölt be, illetve makroỏkonómiai és mikroökonómia funkciónak megfelelō tevékenységet lát el. A kereskedelmi szolgáltatások száma és szinvonala befolyásolhatja a boltválasztást is, valamint profilirozási eszkōzként is funkcionálhat. Ez utóbbi szempontból Tonndorf 10 fỏcsoportba sorolta azokat, a kōvetkezók szerint: az üzlet megkōzelitése, fizikai vásárlási könnyitések, más vásárlási kőnnyitések, tartózkodási „kényelmetlenségek", értékemelő szolgáltatások, hozzáigazitás - más vásárlást elôsegitö szerviz, alkalmazási szolgáltatás, értékesités utáni szerviz, pénzügyi szolgáltatások és más, az áruktól független szolgáltatások.
A termelőtől a fogyasztóig az árunak számos útja létezik. Ez egyrészt függ az előállitott termék jellegétől, hogy fogyasztási cikk vagy termelési eszkōz, az áru eltarthatóságától, speciális szállitási illetve kezelési igényétôl. A klasszikus útnak a termelö — nagykereskedō — kiskereskedō — fogyasztó rangsort nevezik, bár olykor a nagykereskedōnél még egy szaknagykereskedés is bekapcsolódik.

\subsection{Nagykereskedōk és szolgáltatásaik}

A nagykereskedőket három csoportba szokták sorolni aszerint, hogy milyen szolgáltatásokat nyújtanak a kiskereskedőnek. A klasszikus nagykereskedő névvel illetik a szolgáltatások teljes skáláját felvonultató nagykereskedőt. A korlátozott funkciót betöltő nagykereskedő̉ket szokták $\mathrm{C}+\mathrm{C}$-nek nevezni, mely angol rōvidités Cash and Carry, magyarra forditva tōbbféleképpen is éretelmeznek. Fogd és Vidd-ként az óriásplakátokon, mig a szó szerinti forditás a fizesd és vidd. $A C+C$ nagykereskedök nem vállalnak kiszállitást a kiskereskedelmi egységeknek, és nincs fizetési határidö, mely beszerzési társulásnál, jelentős mennyiségnél akár $6-8$ hét is lehet.

Új forma a polcfeltöltö nagykereskedelem, melyet az angol rackjobber szó ir le. A hagyományos nagykereskedelmi feladatok ellátása mellett az árukat az eladás helyszinéig figyelemmel kiséni, garanciát vállal az általa bérelt polcon levő árukért.

\subsection{Kiskereskedelmi szolgáltatások}

A szolgáltatások sztenderdizáltásága kockázati tipusai szerint a „tömegszolgáltatás" kategóriájába tartozik, a kiskereskedelmi szolgáltatásnál a versenyelőny súlypontja a kapcsolat és a termelékenység, az interakció és az egyediesités foka alacsony (sztenderdizált) és a munkaintenzitás (hozzáadott érték) a frontvonalban magas. (Veres [1998] 67. old.).

A kiskereskedelmi tevékenységet kiegészitő szolgáltatások jelentősége nó, mivel növeli a termékek hasznossági szintjét, és versenyelönyt

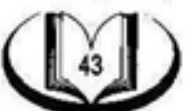


Földi Katalin: Növekvŏ koncentráció, élesebb verseny

\section{1. táblázat}

\section{A kiskereskedelmi szolgáltatások típusai}

\begin{tabular}{|c|c|c|c|}
\hline $\begin{array}{c}\text { Csoportositás } \\
\text { szempontja }\end{array}$ & & Szolgatitatás megnevezése & Gyakorlati péida \\
\hline \multirow[t]{3}{*}{$\begin{array}{l}\text { Értékesités } \\
\text { szakaszai } \\
\text { szerint }\end{array}$} & $\begin{array}{l}\text { Értékesítés elôkészitése } \\
\text { során }\end{array}$ & $\begin{array}{l}\text { információnyúitás-tanácsa } \\
\text { dás elôrendeles }\end{array}$ & $\begin{array}{l}\text { lakberendezés, } \\
\text { szépségápolás, } \\
\text { szabásminta katalógus, } \\
\text { telefon, Internet }\end{array}$ \\
\hline & Értékesités közben & $\begin{array}{l}\text { méretreigazitás, ellenérték } \\
\text { rendezése }\end{array}$ & $\begin{array}{l}\text { konfekció, divatáru, } \\
\text { hitelügyintézés, bankkártya } \\
\text { hasznalat }\end{array}$ \\
\hline & Vásárlás után & $\begin{array}{l}\text { házhozszálitís, beépités, } \\
\text { beúzemelés, } \\
\text { összeszerelés }\end{array}$ & $\begin{array}{l}\text { bútor, tüzép, mũszaki } \\
\text { cikkek }\end{array}$ \\
\hline \multirow[t]{2}{*}{$\begin{array}{l}\text { Szolgáttatás } \\
\text { jellege }\end{array}$} & Termékhez kapcsolódó & $\begin{array}{l}\text { házhozszállitás, } \\
\text { ajándékcsomagolás, } \\
\text { szervizszolgâltatás }\end{array}$ & $\begin{array}{l}\text { bútor, édességek, kozmeti- } \\
\text { kumok, gépjármúvek }\end{array}$ \\
\hline & $\begin{array}{l}\text { Értékesitési } \\
\text { kapcsolódó }\end{array}$ & $\begin{array}{l}\text { ũzletkōzpont, } \\
\text { bevásárlóközpont, } \\
\text { gépjámmū, } \\
\text { márkakereskedés }\end{array}$ & $\begin{array}{l}\text { kulcsmásolás, javitás, } \\
\text { vendéglátás, szervizelés }\end{array}$ \\
\hline \multirow{2}{*}{$\begin{array}{l}\text { Fogyasztó } \\
\text { kölsége szerint }\end{array}$} & Költségtéritéses & ajảndék-feliratozás & szeszes italok, édességek \\
\hline & Költségtérités nélkūi & bankkártya-szolgáltatás & kártyầval történó fizetés \\
\hline
\end{tabular}

Forrás: Pénzes Gyŏrgyné-Lászlo Éva: Kereskedelmi marketing 68. p.

jelent a termék kiterjesztett szintjén. Nem tartós a versenyelóny, mivel a versenytársak által könnyen másolhatóak a kiskereskedelmi szolgáltatások.

A szoigáltatásokat két irányból értékelik, egyrészt a kereskedelmi vállalat, másrészt a fogyasztó szempontjából. A kereskedelmi vállalat mérlegeli, hogy a konkrét szolgáltatás milyen költséggel jár, azt a vásárló igényli-e, lilletve, hogy a fogyasztónak téritéssel vagy ingyen kinálja-e?

A szakirodalomban mindinkább elfogadottá válik a versenyelöny piaci közelitése. Eszerint a versenyelöny megszerzésben nagy fontosságú, hogy versenytársainknál sikkeresebben növeljük kínálatunk értékét, vagyis magasabb „fogyasztói" értéket hozzunk létre. A szolgáltatások terén, annak ismerete, hogy kinálatunk jellemzói miként hatnak a fogyasztók értékitéletére, meghatározó lehet versenystratégiánk kialakitásában. (Birman [2001] 29. old.)
Számos csoportositása létezik a kiskereskedelmi szolgáltatásoknak, ezek egyikét az 1. táblázat tartalmazza.

A Progressziv magazin érdekes szempontból vizsgálta a kereskedelmet. A cikk fócíme megtévesztõ, mely szerint Szolgáltatások szinvonala - mérlegen a 2006-os év. Valójában a köszönési arányt vizsgálta az adott évben már 8. alkalommal.

Egy keleti mondás szerint, aki nem tud mosolyogni, az ne akarjon boltot nyitni. Az eladók viszont úgy nyilatkoztak, hogy ennyi pénzért, ilyen nagy leterheltség mellett kinek van kedve mosolyogni? Hofi Géza klasszikus vice szerint: Tud úszni? És ha megfizetem?

Az Auchannál udvariassági szempontból a pénztárosok kimagasióan teljesitenek. Pedig ugyanaz a munkaerópiac, ahonnan munkatársakat toboroznak, a hipermarket általánosan alacsony árszinvonala miatt, még a bér és a béren kivüli juttatások sem magasabbak, mint a 
tōbbi hipermarketben. A titok igazából nem is titok. Az első a munkakör elnevezése: pénztáros menedzser, akinek elegáns irodista egyenruha jár. Büszkén ülhetnek a birodalmukban, mert a diszletek is presztizst sugároznak.

A kōszönést három ponton vizsgálták: a pénztáraknál, csemege pultnál és a zöldség osztályon. A pénztáraknál egyértelmũen a hipermarketek a nyertesek, különōsen az Auchan. A diszkontok második helyét elsősorban a Penny és a Lidl láncoknak köszönheti, a bronzérmesek a szupermarketek lettek. $A$ csemegepultnál az elsö helyet a szupermarketek vitték el, második helyre a hipermarketek jutottak. Spar-csoport a nyertes, az Auchan esetében a legnagyobb a kontraszt a pénztárhoz képest. A zöldség osztályon a legjobb vevőkiszolgálást ott találták, ahol nem őnkiszolgáló mérleg van, hanem egy eladó méri az árut.

Vagy a köszönéssel csak azt akarták kompenzálni, hogy percekig kellett vámi rájuk? (Progressziv magazin „fantomvásárlója* [2006] 22. old.)

\section{6. Összefoglalás}

A bevezetésben emlitett célkitũzésemkor még nem tudtam, hogy milyen szélmalomharcot vállalok. A szélmalom, mellyel szemben nem győzz-

\section{Irodalom}

Biman Erzsebet: Fogyasztói értékitélet és versenyelóny a lakossági pénzügyi szolgáltatásoknál - egy kutatási program = Nemze屯kōzi marketing 2001/9 29-38. p.

Illés Iván: A tercier szektor jellege, társadalmi-gazdasági szerepe, fejōóési sajâtosságai fejezet (Magyarorszàg társadalmi-gazdasági foldrajza szerkesztó: Perczel Gyơrgy) Budapest: ELTE Eötvōs Kladó 2003. 633 p.

Jász-Nagykun-Szolnok megye az Európai Unió kapujäban = Jász-Nagykun-Szolnok megye Ōnkormányzata 2004 április

Lászlo Éva - Deák Attila: Termék ès szoigáitatás menedzs. ment. Szolnok: Szolnokd Fóiskola 1998. elektronikus formattumú föiskolai jegyzet

Leader Program - a videken épūió Európa. Letôltés dátuma: 2008. január 14

Németh György - Papp llona: Szolgáltatási menedzsment. hettem, a kiskereskedelmi szolgáltatások megyénként, illetve településenkénti számontartása, elemzése. Sem a föiskolai kōnyvtárban, sem az interneten nem akadtam releváns irodalomra. Még a Progressziv magazin sem igazán a kiskereskedelmi szolgáltatásokat kutatta. AMc'Carthy által meghatározott $4 \mathrm{P}$ marketingeszkōzei, a szolgáltatásoknál 7 P-re bo̊vūl. Az angol rōviditésekböl a 3 „plusz" P az ember (People), a folyamat (Process) és a tárgyi elemek (Physical evidence). Az emberi tényezõnél csak egy dolgot vizsgáltak, mégpedig a 10 minöségparaméterböl az egyikhez, az udvariassághoz tartozó köszönési kvótát.

lgy csak azzal a feltételezéssel élhetek, hogy a több és nagyobb eladóterũ kiskereskedelmi egységgel rendelkező települések vásárlói tōbb és magasabb színvonalú kiskereskedelmi szolgáltatást vehetnek igénybe. Valamint a nagyobb vásárlóerővel rendelkező háztartásokra is igaz az elóbbi feltevésem.

Mivel egy olyan területre akadtam, mely nem kerūlt feltárásra, és ami kapcsolódik a Ph.D témámhoz, igy a jôvőbeni primer kutatásom keretében mind a kvantitativ mind a kvalitativ kutatás keretében vizsgálni fogom a kiskereskedelmi szolgáltatásokat is. Így akkor a jelen dolgozatban felvetődő kérdésekre választ kaphatok majd.

(Szolgátatałsok a nemzetgazdaságban) Budapest Aula Kiado 1995.

OrientPress - MCOnet KSH felmérés. Letōltés dátuma: 2008. 01. 14.

Papp llona (szerkesztor); Szolgáltatások a harmadik évezredben. Budapest: Aula Kiado 2003, 542 p.

Pénzes Gyōrgyné - László Éva. Kereskedelmi marketing. Szolnok: Szolnoki Föiskola 2004. 171 p.

Progresszí magazin ,fantomvásárlója": Nem a helyezés szamitl = Progressziv magazin 2006. december. 22-23. p.

Tonndorf Hans G.: Kiskereskedelem európai szinwonalon. Budapest: Novorg Kiadó 1997. 226 p.

Veres Zoltán: Szolgáltatás marketing. Budapest: Mûszaki Kōnyvkiadó 1998. 344 p. 